\title{
Chicken Anaemia Virus in Egyptian Broiler; Clinical Signs and Molecular Characterization
}

\author{
Shahira A. Abdelwahab ${ }^{1}$ and Dalia M. H. ${ }^{2}$ \\ shahira_mohamed@vet.suez.edu.eg - dalia_mansour@vet.suez.edu.eg \\ ${ }^{1}$ Virology Department, Faculty of Veterinary Medicine, Suez Canal \\ University \\ ${ }^{2}$ Avian and Rabbit Medicine Depatement, Faculty of Veterinary Medicine, \\ Suez Canal University
}

\begin{abstract}
A total of 18 flocks , 45 day old broiler from Ismailia, Egypt were tested for chicken anemia virus (CAV) using serological evidence and molecular characterization. Tested birds had history of diarrhea, blue wing, depression, and deaths. Necropsy findings were pale liver, severe atrophy of bursa Fabricius and thymus, pale discoloration of the bone marrow and subcutaneous hemorrhages. The viral DNA of the VP1 gene was detected and sequenced. Nucleic acid alignment showed $100 \%$ similarities with many CAV viruses. Antibodies against CAV were detected in $73.9 \%$ of the tested samples using commercial ELISA kit. Hemoglobin $(\mathrm{Hb})$ revealed low percentage $(4.3 \%$ to $8.02 \%$ ), and packed cell volume (PCV) were measured and showed anemic level (22.5 to 34.2). The data strengthen the concept that CAV may have a negative economic impact on the chicken industry in Ismailia.
\end{abstract}

Key words: antibodies, chickens, chicken anemia virus, immunosuppression.

\section{Introduction}

Chicken anemia virus (CAV) is a worldwide disease of most poultry species causing great economic losses (Chowdhury et al., 2002; Schat, 2009). It transmitted either vertically or horizontally (McNulty, 1991; Sommer and Cardona, 2003). It has been detected in most commercial poultry farms, with a high seroprevalence (Owoade et al., 2004).

CAV has Clinical and subclinical forms (Davidson et al., 2004; Jorgensen et al., 1995). Clinical form characterized by severe aplastic anemia, generalized lymphoid atrophy of hematopoietic and lymphoid organs, intramuscular and subcutaneous hemorrhages. retarded growth and high mortality (Sommer and Cardona, 2003). It was enhances susceptibility to other infectious disease agents through reducing response to vaccinations (Adair, 2000; Otaki et al., 1988; Todd, 2000). In older birds the infection is mainly subclinical. Chicken anemia virus (CAV) is the only member of the genus Gyrovirus 
of the family Circoviridae (Niu et al., 2019). CAV is non-enveloped, icosahedral symmetry and measures 22-26 $\mathrm{nm}$ in diameter (McNulty et al., 1990; Pope, 1991). The CAV genome is negative-sense, circular, single-stranded DNA (Gelderblom et al., 1989; Noteborn et al., 1991; Todd et al., 1990), The genome encodes for 3 viral proteins (VP1, VP2 and VP3); VP1 is the capsid protein; VP2is needed for proper folding of VP1 and VP3( apoptin) induces apoptosis in infected cells (Noteborn, 2004) . Diagnosis of CAV infections can be made by detecting infectious virus, virus antigen, virus DNA, or virusspecific antibodies (Chettle et al., 1991; Chettle et al., 1989).

Aim of the study was to evaluate seroprevalence of CAV in broilers, determining some pathological indices and hematological parameters, then confirm the serological status by detection and analysis of the viral DNA using PCR and sequencing.

\section{Materials and Methods \\ 1-Chicken}

A total of 180 samples were collected from broilers aged 45 days old. Samples were collected from apparently healthy randomly selected fom18 broiler flock in Ismailia, Eygpt during winter and summer of 2010. Samples collected from each chicken were whole blood, serum, thymus, spleen, and bursa of fabricus.

2-Whole blood and sera
Whole blood samples were used for determination of packed cell volume (PCV) values and hemoglobin \%. Sera were separated and used to detect $\mathrm{HI}$ antibody titer against NDV and CAV. Total of 5 randomly selected whole blood samples, one from each of 5 flocks, were used for DNA extraction and genetic analysis.

The packed cell volume (PCV) was determined on a blood sample collected from each bird before slaughtering using the microhematocrit capillary tube method (Goodwin et al., 1991).

\section{3-ELISA for CAV antibodies}

A commercial ELISA kit was used to detect specific antibodies against CAV (IDEXX Flock Chek CIAV), according to the manufacturer's instructions; A serum dilution of 1:10 was used. Optical density values were read at $650 \mathrm{~nm}$ using a Tecam Sunrise ELISA reader.

\section{4-Nucleic acid extraction}

QIAamp DNA Mini Kit (QIAGEN, USA) was used according to the manufacturer's instructions to extract DNA from 5 randomly selected samples from different farms.

\section{5-Partial Amplification of CAV- VP1}

A Nested PCR was used for amplification of VP1 fragment of chicken anaemia virus as described previously by (Cardona et al., 2000). The forward and reverse primers were used to amplify $386 \mathrm{bp}$ fragment. The sequence of both primers were shown in table (1). 
The nested PCR was done as described by (Cardona et al., 2000).In the first $P C R$ reaction primers $\mathrm{O} 3 \mathrm{~F}$ and $\mathrm{O} 3 \mathrm{R} w e r e$ used, and was programmed as follow; $5 \mathrm{~min}$ at $94{ }^{\circ} \mathrm{C}$ followed by 35 cycles consisting of $1 \mathrm{~min}$ at $94{ }^{\circ} \mathrm{C}, 2 \mathrm{~min}$ at $45^{\circ} \mathrm{C}$ and $1 \mathrm{~min}$ at $72{ }^{\circ} \mathrm{C}$, followed by $10 \mathrm{~min}$ at $72{ }^{\circ} \mathrm{C}$. The nested PCR reaction (second step) was done using primers $\mathrm{N} 3$ and $\mathrm{N} 4$ using $1 \mathrm{ul}$ from the first reaction. the procedures as described before; an initial denaturation for $5 \mathrm{~min}$ at 94 ${ }^{\circ} \mathrm{C}$, followed by 30 cycles; 2 cycles of $30 \mathrm{sec}$ at $94{ }^{\circ} \mathrm{C}, 30 \mathrm{sec}$ at $60{ }^{\circ} \mathrm{C}$ and $30 \mathrm{sec}$ at $72{ }^{\circ} \mathrm{C}$, followed by 2 cycles at a time with the annealing temperature decreasing by $1{ }^{\circ} \mathrm{C}$ down to $56{ }^{\circ} \mathrm{C}$ (totaling 10 cycles), and ending with 20 cycles of $30 \mathrm{sec}$ at $94{ }^{\circ} \mathrm{C}, 30 \mathrm{sec}$ at $55^{\circ} \mathrm{C}$ and $30 \mathrm{sec}$ at $72{ }^{\circ} \mathrm{C}$, followed by $10 \mathrm{~min}$ at 72 ${ }^{\circ} \mathrm{C}$.
The PCR products were analyzed using $1.5 \%$ agarose gel electrophoresis. Infection verified on the basis of detection of a 386 and 209 bp bands from the first and second PCR steps respectively.

\section{6-Sequencing and sequence analysis}

Sequencing of the purified PCR products was done at the Molecular Biology Resources Service (UTK) using an ABI prism dye terminator cycle sequencing reaction kit and ABI 373 DNA.

The purification was done using ExoSAP-IT PCR Product Cleanup (Affymetrix, Ohio,USA). The sequencing was done using nested second step primer N3 of the first PCR product size 386 . The sequence results were analyzed using Mega 6 and the BLAST program in the NCIB website. The trimined sequence clean part yielded $307 \mathrm{bp}$ for sequence analysis.

Table (1): Nested-PCR primers showing target fragment length and location fot each primer pairs on VP1 gene of CIAV

\begin{tabular}{|c|c|c|c|c|}
\hline $\begin{array}{l}\text { primer } \\
\text { name }\end{array}$ & $\begin{array}{l}\text { primer } \\
\text { position } \\
\text { in the } \\
\text { genome }\end{array}$ & Sequence & $\begin{array}{c}\text { PCR } \\
\text { step }\end{array}$ & $\begin{array}{l}\text { Expected } \\
\text { size }\end{array}$ \\
\hline $\mathbf{O 3 F}$ & $452-471$ & 5' CAAGTAATTTCAAATGAACG 3' & \multirow{2}{*}{$\begin{array}{c}\text { First } \\
\text { PCR } \\
\text { step }\end{array}$} & \multirow{2}{*}{ 386bp } \\
\hline O3R & 838-819 & 5' TTGCCATCTTACAGTCTTAT 3, & & \\
\hline N3 & $489-505$ & 5' CCACCCGGACCATCAAC 3' & \multirow{2}{*}{$\begin{array}{c}\text { Second } \\
\text { PCR } \\
\text { step }\end{array}$} & \multirow{2}{*}{ 209bp } \\
\hline N4 & 698-677 & 5'GGTCCTCAAGTCCGGCACATTC3' & & \\
\hline
\end{tabular}




\section{RESULTS}

\section{1-Necropsy and hematological finding}

Chicken showed depression, sunken eye, conjunctivitis, ruffled feather and pale comb and wattles. Some birds had diarrhea and/or blue discoloration of wings (blue wing disease). Necropsy findings were; atrophied lymphoid organs (bursa, thymus anspleen), and hemorrhages on breast, wings, and thigh muscles . Heart showed petechial haemorrhages with hydro-pericaridum. Other findings were noticed as pneumonia, perihepatitis, and air saculitis. Kidneys in some birds were found swollen and pale.

PCV values and hemoglobin; mean values of PCV from different flocks were ranged from 22.5 to 34.2 while mean hemoglobin\% values were ranged from $4.3 \%$ to $8.02 \%$ shown in table (2) .

\section{2-ELISA antibody titers against CAV:}

Antibody titers against CAV of more than 700 were found in 133 samples which considered positive titers according to the manufacturer's guidelines. These samples represent a positive percentage of $73.9 \%$ of 180 tested samples. While 47 samples had titer less than 1-700 which considered negative according to the manufacturer's guidelines representing a negative percentage of $26.1 \%$ of these samples. The details of positive and negative samples from each flock are shown in figure (1) and table (3).

\section{3-Genetic detection and characterization}

All 5 samples used for molecular characterization using nested PCR were positive and produced the target segments (386 bp) of the nucleic acid targeting VP1. Sequence analysis of the obtained PCR products revealed that the full-genome sequence of nucleotides was of $100 \%$ sequence identities similar to CAV strains published on the GENBANK; ACCESSION KP899520, VERSION KP899520.

Table (2): $P C V$, hemoglobin values and percentages of positive in chicken farms in ismailia

\begin{tabular}{|c|c|c|c|c|}
\hline Flocks & $\begin{array}{c}\text { No. of samples } \\
\text { (No. of flocks) }\end{array}$ & $\begin{array}{c}\text { \% of } \\
\text { positive }\end{array}$ & PCV \% & $\begin{array}{c}\text { Hemoglobin } \\
\%\end{array}$ \\
\hline $\mathbf{A}$ & $40(4)$ & $100 \%$ & 22.5 & $4.5 \%$ \\
\hline B & $40(4)$ & $90 \%$ & 25.0 & $4.3 \%$ \\
\hline $\mathbf{C}$ & $20(2)$ & $80 \%$ & 31.6 & $5.6 \%$ \\
\hline $\mathbf{D}$ & $10(1)$ & $70 \%$ & 32.0 & $7.3 \%$ \\
\hline $\mathbf{E}$ & $60(6)$ & $50 \%$ & 34.0 & $7.2 \%$ \\
\hline F & $10(1)$ & $40 \%$ & 34.2 & $8.02 \%$ \\
\hline $\begin{array}{c}\text { Normal } \\
\text { values }\end{array}$ & & & 42.0 & $10.0 \%$ \\
\hline
\end{tabular}


Table (3): ELISA positive values and percentages of Chicken infectious anemia virus in chicken farms in Ismailia:

\begin{tabular}{|c|c|c|c|c|c|}
\hline Group & $\begin{array}{c}\text { No. of samples } \\
\text { (No. of flocks) }\end{array}$ & $\begin{array}{c}\text { ELISA } \\
\text { positive }\end{array}$ & $\begin{array}{c}\text { ELISA } \\
\text { negative }\end{array}$ & $\begin{array}{c}\text { Titer up } \\
\text { to }\end{array}$ & $\begin{array}{c}\% \text { of } \\
\text { positive }\end{array}$ \\
\hline A & $40(4)$ & 40 & 0 & 12301 & $100 \%$ \\
\hline B & $40(4)$ & 36 & 4 & 7062 & $90 \%$ \\
\hline C & $20(2)$ & 16 & 4 & 3674 & $80 \%$ \\
\hline D & $10(1)$ & 7 & 3 & 2228 & $70 \%$ \\
\hline E & $60(6)$ & 30 & 30 & 5474 & $50 \%$ \\
\hline F & $10(1)$ & 4 & 6 & 7048 & $40 \%$ \\
\hline Normal & $180(18)$ & 133 & 47 & $\begin{array}{c}\text { Mean } \\
(2143)\end{array}$ & $\begin{array}{c}\text { Mean } \\
71.6 \%\end{array}$ \\
\hline
\end{tabular}

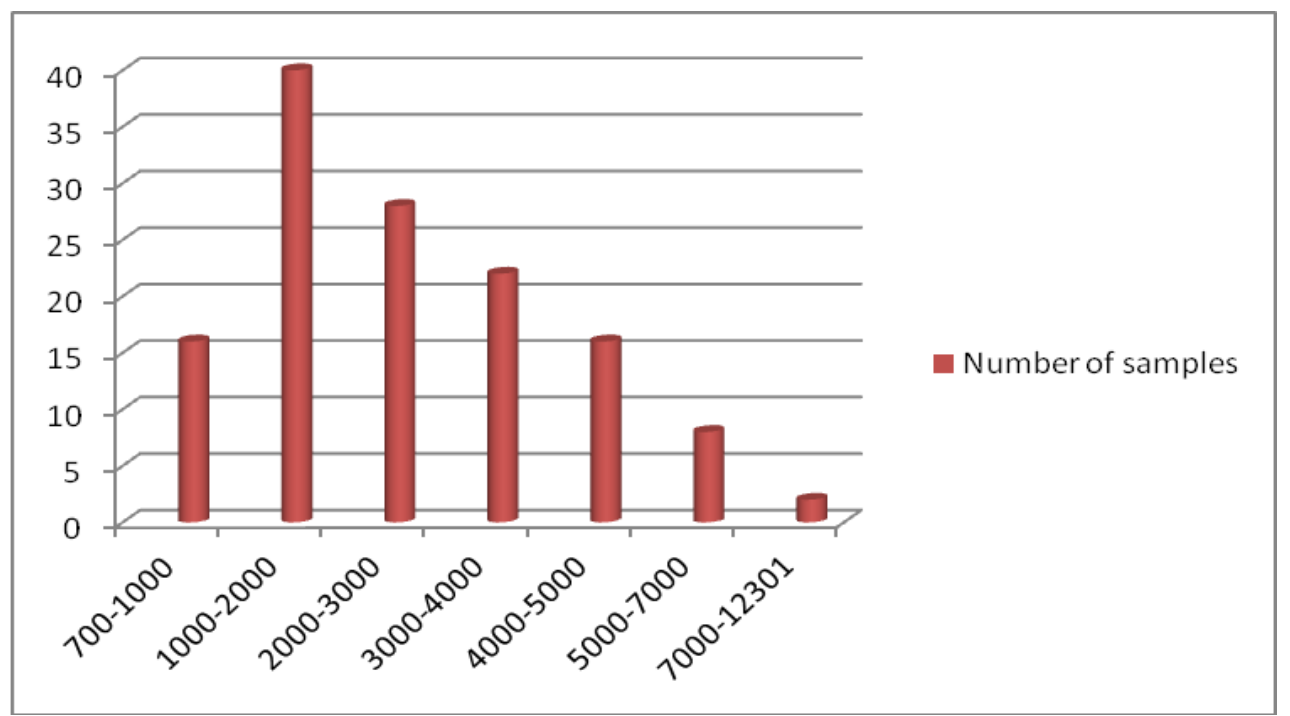

Figure (1): Titer range of ELISApositive samples in birds

\section{Discussion}

In the present study we sought to gain evidence of CAV influence on the health of commercial chicken flocks. The study attempts to contribute to the ongoing debate regarding whether the viral infection causes livability and profitability damages. Several studies indicated the harmful effects of the CIAV clinical and subclinical infection, while others found no significant effects on broiler performance. However, the final effect is the expression of multiple roots, such as management, stresses, genetic background, and additional pathogens (Hagood et al., 2000).

Hagood et al., 2000. demonstrated that CIAV was more often detected 
in diseased than in healthy flocks, and that finding was associated with thymus and bursal atrophy accompanied by increased mortality and condemnation rates (Pope, 1991). The potential harmful effect of CAV in healthy commercial flocks might be affected by the environment, management factors, and hormonal changes, which may affect the onset of the CIAV replication by activating or affecting cellular transcriptional factors $(\boldsymbol{L i}$ and Cui, 2007).

Necropsy findings and postmortem changes found in examined chickens were indicative for chicken anemia virus infection as atrophied lymphoid organs and hemorrhages on breast, wings, and thigh muscles were found (Brentano et al., 1991; Chettle et al., 1989). Heart and Kidneys lesions in some birds were found to representable to the viral infection .

PCV values and hemoglobin; mean values of PCV from different flocks were ranged from 22.5 to 34.2 , this low range of $\mathrm{PCV}$ value in comparison to the normal values greater than or equal to $40 \%-43 \%$ supportive that this was caused by the CAV infection (Goodwin and Brown, 1992). While mean hemoglobin\% values were ranged from $4.3 \%$ to $7.02 \%$ and theses values revealed that the chicken experienced anemia (Sommer and Cardona, 2003; Wani et al., 2014). Serological surveys have shown that CAV infection is widespread in industrial poultry (Schat and Schukken, 2010).

Presence of anti-CAV antibodies in tested flock's sera indicates that chickens may be vertically or horizontally infected or even acquired the antibodies passively from their breeders via yolk or even by contaminated vaccines (Stabili et al., 2016). The passively acquired antibodies are unlikely because all tested commercial layer and broiler flock's sera were collected after the age of 3 weeks, the time required for maternal antibodies to decay as mentioned by (McNulty et al., 1989). The presence of CAV antibodies in tested flock's sera with no history of clinical signs or lesions suggestive to CAV infection or vaccination against the virus certainly indicates that the source of anti-CAV antibodies detected in tested sera is the horizontally acquired CAV infection through direct and indirect contact with virus- contaminated dust, water or feed with feces specially that the virus shows extreme physical and chemical resistance to inactivation and so persists for long in poultry houses (Goryo et al., 1985). Although subclinical CAV infection does not produce clinical symptoms of the disease, it is immunosuppressive (McConnell et al., 1993; McNulty et al., 1991). As detected by, Emikpe et al. (2005) was $66.2 \%$ While Oluwayelu \& Todd, 2008, and Bulgaria may reflect the differences in the environment conditions, husbandry 
practices and samples size also The actual exposure to CAV, most likely from the environment, appears to have occurred at around 28 days of age although the flock may have been susceptible earlier (Emikpe et al., 2005; Oluwayelu et al., 2008; Todd et al., 2008).

Comingling of birds from different generations in the same flock, a common vertical transmission, which is an important way of viral spread at the conditions of industrial poultry farming due to the ability of CAV to persist in the ovaries of laying hens even at a presence of circulating antibodies (Brentano et al., 2005; Hoop et al., 1992), also may play a role in CAV epidemiology. Our study detected CAV seroreagents in all flocks surveyed. These results are indicative for the high rate of environmental contamination and reflect the possibility for easy virus transmission between farms by environmental factors.

Seropositivity to CAV does not necessarily relate to overt disease, it indicates that birds have undergone at least subclinical infection with possible consequent immunosuppressive effects such as increased predisposition to other viral or bacterial infections or suboptimal response to vaccination. Thus, considering its widespread occurrence, CAV infection must be taken into account as a risk factor related to the epizootological picture of backyard chicken flocks.
The current study used the primers coding for the casid viral protein VP1. The circulating chicken infectious anemia virus has the viral capsid protein VP1 $(51 \mathrm{KDa})$ which is relatively conserved compared to the other two viral nonstructural proteins VP2 (24KDa) and viral apotin protein VP3 $(13 \mathrm{KDa})$ which are highly stable and highly conservative, the neutralizing antibodie are produced against VP1 and VP2 (Koch et al., 1995).

The obtained nested-PCR product was sequenced, the nucleotide identity was $100 \%$ to most CAV strains when compared by aligning. This result is in agreement with studies performed in different placed worldwide (AboElkhair et al., 2014; Erfan et al., 2018; Hailemariam et al., 2008; Ou et al., 2018). The Vietnamese CAV strains were closely related to the Chinese, Taiwanese, and USA strains (Van Dong et al., 2019).

While the deduced amino acid sequence of the portion of VP1 determined differed from that of most Alabama CAV sequences previously determined at five positions and was different from all other CAV VP1 deduced amino acid sequences available, with the exception of Alabama 98-7370, in at least one position

\section{Conclusion}

Chicken infectious anemia virus infection is a worldwide disease with clinical and subclinical forms and it has been described in most countries 
where chickens are raised commercially. The infection have a high economic losses due to destructive effect on lymphoid organs leading to immunosuppression and subsequently vaccination failure and complications with other infections. This study revealed a high CAV infection in Ismailia governorate clinically and serological testing showed $68 \%$ positive by ELISA test and genetic analysis revealed that the circulating virus in positive sampled are $100 \%$ similar to the worldwide strains. Further investigations are necessary to evaluate the economic losses caused by CAV and the cost-benefit of vaccination.

\section{References}

AboElkhair, M., Abd El-Razak, A.G., Metwally, A.E., (2014). Molecular characterization of chicken anemia virus circulating in chicken flocks in egypt. Advances in virology 2014, 797151.

Adair, B.M., (2000). Immunopathogenesis of chicken anemia virus infection. Developmental and comparative immunology 24, 247-255.

Brentano, L., Lazzarin, S., Bassi, S.S., Klein, T.A., Schat, K.A. (2005). Detection of chicken anemia virus in the gonads and in the progeny of broiler breeder hens with high neutralizing antibody titers. Veterinary microbiology 105, 65-72. Brentano, L., Mores, N., Wentz, I., Chandratilleke, D., Schat, K.A.,
(1991). Isolation and identification of chicken infectious anemia virus in Brazil. Avian diseases 35, 793-800.

Cardona, C.J., Oswald, W.B., Schat, K.A., (2000). Distribution of chicken anaemia virus in the reproductive tissues of specificpathogen-free chickens. The Journal of general virology 81, 2067-2075.

Chettle, N.J., Eddy, R.K., Saunders, J., Wyeth, P.J., (1991). A comparison of serum neutralisation, immunofluorescence and immunoperoxidase tests for the detection of antibodies to chicken anaemia agent. The Veterinary record 128, 304-306.

Chettle, N.J., Eddy, R.K., Wyeth, P.J., Lister, S.A., (1989). An outbreak of disease due to chicken anaemia agent in broiler chickens in England. Vet Rec 124, 211-215.

Chowdhury, S.M., Omar, A.R., Aini, I., Hair-Bejo, M., Jamaluddin, A.A., Kono, Y., Darus, A., Yatim, H.M., (2002). Isolation, identification and characterization of chicken anaemia virus in Malaysia. $\mathrm{J}$ Biochem Mol Biol Biophys 6, 249-255.

Davidson, I., Kedem, M., Borochovitz, H., Kass, N., Ayali, G., Hamzani, E., Perelman, B., Smith, B., Perk, S., (2004). Chicken infectious anemia virus infection in Israeli commercial flocks: virus amplification, clinical signs, performance, and antibody status. Avian diseases 48, 108-118.

Emikpe, B.O., Oluwayelu, D.O., Ohore, O.G., Oladele, O.A., Oladokun, A.T., (2005). 
Serological evidence of chicken anaemia virus infection in Nigerian indigenous chickens. The Onderstepoort journal of veterinary research 72, 101-103.

Erfan, A.M., Selim, A.A., Naguib, M.M., (2018). Characterization of full genome sequences of chicken anemia viruses circulating in Egypt reveals distinct genetic diversity and evidence of recombination. Virus research 251, 78-85.

Gelderblom, H., Kling, S., Lurz, R., Tischer, I., von Bulow, V., (1989).

Morphological characterization of chicken anaemia agent (CAA). Archives of virology 109, 115-120.

Goodwin, M.A., Brown, J., (1992). Inability of so-called chicken anemia agent (CAA) infections to be diagnosed by anemia and hematopoietic organ atrophy alone. Avian Dis 36, 353-355.

Goodwin, M.A., Steffens, W.L., Davis, J.F., Brown, J., Latimer, K.S., Dickson, T.G., (1991). Diagnoses of infections by the socalled chick anemia agent: anemia and direct transmission electron microscopic detection of virus. Avian diseases 35, 869-871.

Goryo, M., Sugimura, H., Matsumoto, S., Umemura, T., Itakura, C., (1985). Isolation of an agent inducing chicken anaemia. Avian pathology : journal of the W.V.P.A 14, 483-496.

Hagood, L.T., Kelly, T.F., Wright, J.C., Hoerr, F.J., (2000). Evaluation of chicken infectious anemia virus and associated risk factors with disease and production losses in broilers. Avian diseases 44, 803-808.

Hailemariam, Z., Omar, A.R., Hair-Bejo, M., Giap, T.C., (2008). Detection and characterization of chicken anemia virus from commercial broiler breeder chickens. Virology journal 5, 128.

Hoop, R.K., Guscetti, F., Keller, B., (1992). [An outbreak of infectious chicken anemia in fattening chickens in Switzerland]. Schweizer Archiv fur Tierheilkunde 134, 485-489.

Jorgensen, P.H., Otte, L., Nielsen, O.L., Bisgaard, M., (1995). Influence of subclinical virus infections and other factors on broiler flock performance. British poultry science $36,455-463$.

Koch, G., van Roozelaar, D.J., Verschueren, C.A., van der Eb, A.J., Noteborn, M.H., (1995). Immunogenic and protective properties of chicken anaemia virus proteins expressed by baculovirus. Vaccine 13, 763-770.

Li, Y.P., Cui, Z.Z., (2007). [Pathogenicity and genomic sequence comparison of a chicken infectious anemia virus field isolate]. Wei sheng wu xue bao = Acta microbiologica Sinica 47, 894898.

McConnell, C.D., Adair, B.M., McNulty, M.S., (1993). Effects of chicken anemia virus on cellmediated immune function in chickens exposed to the virus by a natural route. Avian diseases 37, 366-374. 
McNulty, M.S., (1991). Chicken anaemia agent: a review. Avian pathology : journal of the W.V.P.A 20, 187-203.

McNulty, M.S., Connor, T.J., McNeilly, F., Spackman, D., (1989). Chicken anemia agent in the United States: isolation of the virus and detection of antibody in broiler breeder flocks. Avian diseases 33, 691-694.

McNulty, M.S., Curran, W.L., Todd, D., Mackie, D.P., (1990). Chicken anemia agent: an electron microscopic study. Avian diseases 34, 736-743.

McNulty, M.S., McIlroy, S.G., Bruce, D.W., Todd, D., (1991). Economic effects of subclinical chicken anemia agent infection in broiler chickens. Avian diseases 35, 263-268.

Niu, J.T., Yi, S.S., Dong, G.Y., Guo, Y.B., Zhao, Y.L., Huang, H.L., Wang, K., Hu, G.X., Dong, H., (2019). Genomic Characterization of Diverse Gyroviruses Identified in the Feces of Domestic Cats. Scientific reports 9, 13303.

Noteborn, M.H., (2004). Chicken anemia virus induced apoptosis: underlying molecular mechanisms. Veterinary microbiology 98, 89-94.

Noteborn, M.H., de Boer, G.F., van Roozelaar, D.J., Karreman, C., Kranenburg, O., Vos, J.G., Jeurissen, S.H., Hoeben, R.C., Zantema, A., Koch, G., et al., (1991). Characterization of cloned chicken anemia virus DNA that contains all elements for the infectious replication cycle. Journal of virology 65, 3131-3139.

Oluwayelu, D.O., Todd, D., Olaleye, O.D., (2008). Sequence and phylogenetic analysis of chicken anaemia virus obtained from backyard and commercial chickens in Nigeria. The Onderstepoort journal of veterinary research 75 , 353-357.

Otaki, Y., Tajima, M., Saito, K., Nomura, Y., (1988). Immune response of chicks inoculated with chicken anemia agent alone or in combination with Marek's disease virus or turkey herpesvirus. Nihon juigaku zasshi. The Japanese journal of veterinary science 50, 1040-1047. Ou, S.C., Lin, H.L., Liu, P.C., Huang, H.J., Lee, M.S., Lien, Y.Y., Tsai, Y.L., (2018). Epidemiology and molecular characterization of chicken anaemia virus from commercial and native chickens in Taiwan. Transboundary and emerging diseases 65, 1493-1501.

Owoade, A.A., Oluwayelu, D.O., Fagbohun, O.A., Ammerlaan, W., Mulders, M.N., Muller, C.P., (2004). Serologic evidence of chicken infectious anemia in commercial chicken flocks in southwest Nigeria. Avian diseases 48, 202-205.

Pope, C.R., 1991. Chicken anemia agent. Veterinary immunology and immunopathology 30, 51-65.

Schat, K.A., (2009). Chicken anemia virus. Current topics in microbiology and immunology 331, 151-183. 
Schat, K.A., Schukken, Y.H., (2010). An 8-year longitudinal survey for the presence of antibodies to chicken infectious anemia virus in two specific-pathogen-free strains of chickens. Avian diseases 54, 46-52.

Sommer, F., Cardona, C., (2003). Chicken anemia virus in broilers: dynamics of the infection in two commercial broiler flocks. Avian diseases 47, 1466-1473.

Stabili, L., Fraschetti, S., Acquaviva, M.I., Cavallo, R.A., De Pascali, S.A., Fanizzi, F.P., Gerardi, C., Narracci, M., Rizzo, L., (2016). The Potential Exploitation of the Mediterranean Invasive Alga Caulerpa cylindracea: Can the Invasion Be Transformed into a Gain? Mar Drugs 14.

Todd, D., (2000). Circoviruses: immunosuppressive threats to avian species: a review. Avian pathology : journal of the W.V.P.A 29, 373-394. Todd, D., Creelan, J.L., Mackie, D.P., Rixon, F., McNulty, M.S., (1990). Purification and biochemical characterization of chicken anaemia agent. The Journal of general virology 71 ( $\mathrm{Pt} 4$ ), 819-823.

Todd, D., Fringuelli, E., Scott, A.N., Borghmans, B.J., Duchatel, J.P., Shivaprasad, H.L., Raidal, S.R., Abadie, J.X., Franciosini, M.P., Smyth, J.A., (2008). Sequence comparison of pigeon circoviruses. Research in veterinary science 84, 311-319.

Van Dong, H., Tran, G.T.H., Van Nguyen, G., Dao, T.D., Bui, V.N., Huynh, L.T.M., Takeda, Y., Ogawa, H., Imai, K., (2019). Chicken anemia virus in northern Vietnam: molecular characterization reveals multiple genotypes and evidence of recombination. Virus Genes 55, 643-653.

Wani, M.Y., Dhama, K., Latheef, S.K., Barathidassan, R., Tiwari, R., Chakraborty, S., Chawak, M.M., Singh, S.D., (2014). Experimental pathological studies of an Indian chicken anaemia virus isolate and its detection by PCR and FAT. Pakistan journal of biological sciences : PJBS 17, 802-811. 


\section{الملخص العربي}

فيروس انيميا الاجاج المعدي من الأمراض الفيروسية العالمية و التي تتسبب في خسائر اقتصادية

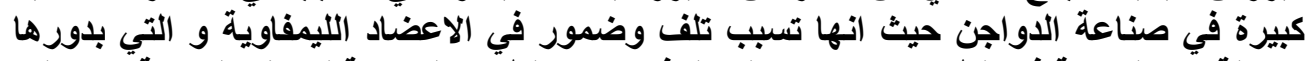

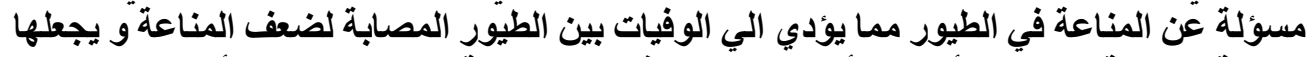

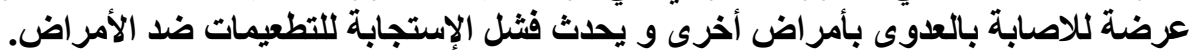

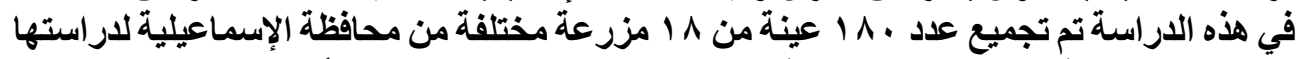

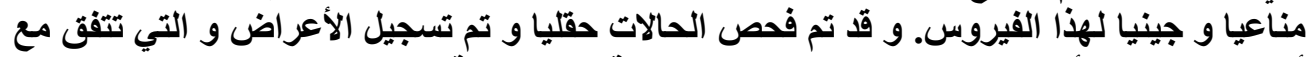

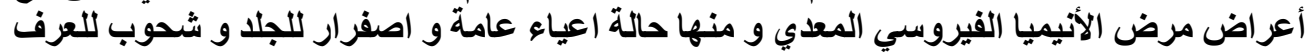

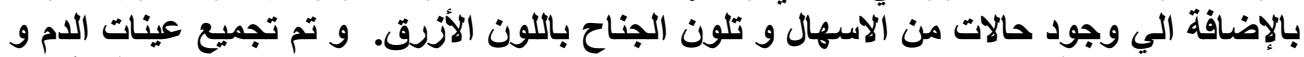

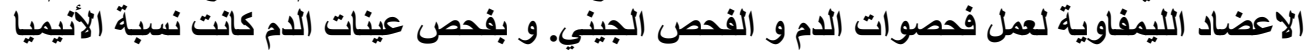

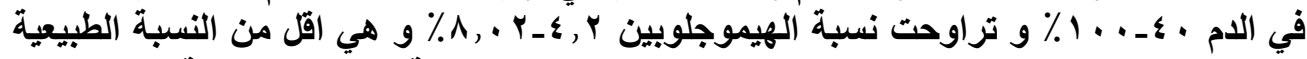

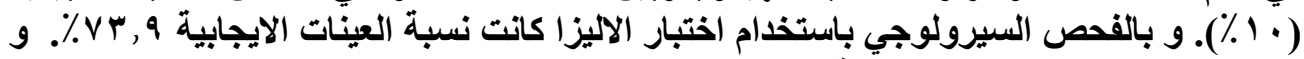

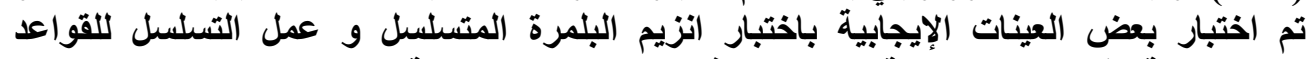

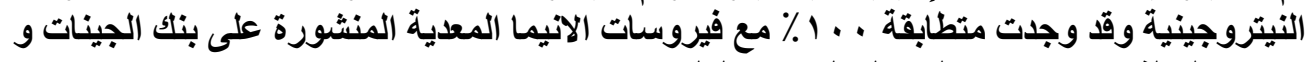

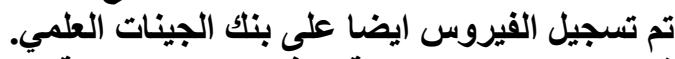

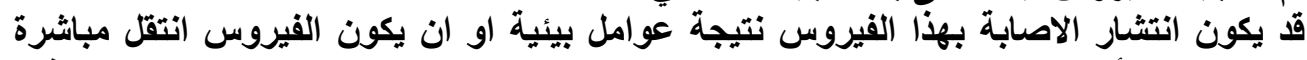

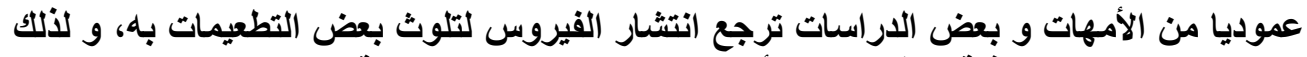
يجب عمل دراسات اضافية للوقوف على أسباب انتشار الفيروس و كيفية القضاء التضاء عليه. 